\title{
The effects of antibiotics on the microbiome throughout development and alternative approaches for therapeutic modulation
}

\author{
Amy Langdon ${ }^{1,2+}$, Nathan Crook ${ }^{1,3+}$ and Gautam Dantas ${ }^{1,3,4,5^{*}}$
}

\begin{abstract}
The widespread use of antibiotics in the past 80 years has saved millions of human lives, facilitated technological progress and killed incalculable numbers of microbes, both pathogenic and commensal. Human-associated microbes perform an array of important functions, and we are now just beginning to understand the ways in which antibiotics have reshaped their ecology and the functional consequences of these changes. Mounting evidence shows that antibiotics influence the function of the immune system, our ability to resist infection, and our capacity for processing food. Therefore, it is now more important than ever to revisit how we use antibiotics. This review summarizes current research on the short-term and long-term consequences of antibiotic use on the human microbiome, from early life to adulthood, and its effect on diseases such as malnutrition, obesity, diabetes, and Clostridium difficile infection. Motivated by the consequences of inappropriate antibiotic use, we explore recent progress in the development of antivirulence approaches for resisting infection while minimizing resistance to therapy. We close the article by discussing probiotics and fecal microbiota transplants, which promise to restore the microbiota after damage of the microbiome. Together, the results of studies in this field emphasize the importance of developing a mechanistic understanding of gut ecology to enable the development of new therapeutic strategies and to rationally limit the use of antibiotic compounds.
\end{abstract}

\section{Collateral harm from the use of antibiotics}

The beneficial impact that the control of bacterial pathogens has had on our standard of living is difficult to overstate. However, our control over microbial disease is diminishing. Human pathogens have repeatedly acquired the genetic capacity to survive antibiotic treatment owing to heavy selective pressures resulting from widespread antibiotic use. The incidence of antibioticresistant infections is rising sharply, while the rate of discovery of new antibiotics is slowing, in such a way that the number of withdrawals of antibiotics from healthcare exceeds the number of approvals by a factor of two [1].

\footnotetext{
* Correspondence: dantas@wustl.edu

tEqual contributors

${ }^{1}$ Center for Genome Sciences, Washington University School of Medicine, Campus Box 8510, 4515 McKinley Research Building, St. Louis, MO 63108, USA ${ }^{3}$ Department of Pathology \& Immunology, Washington University School of Medicine, Campus Box 8118, 660 South Euclid Ave, St. Louis, MO 63110, USA Full list of author information is available at the end of the article
}

In 2015, antibiotic-resistant pathogens were estimated to cause over 50,000 deaths a year in Europe and the USA. The toll is projected to rise to 10 million deaths per year worldwide by 2050 [2]. These figures suggest we are reaching the end of the antibiotic era.

In addition to the development of resistance, the use of antibiotics heavily disrupts the ecology of the human microbiome (i.e., the collection of cells, genes, and metabolites from the bacteria, eukaryotes, and viruses that inhabit the human body). A dysbiotic microbiome may not perform vital functions such as nutrient supply, vitamin production, and protection from pathogens [3]. Dysbiosis of the microbiome has been associated with a large number of health problems and causally implicated in metabolic, immunological, and developmental disorders, as well as susceptibility to development of infectious diseases [4-11]. The wide variety of systems involved in these diseases provides ample cause for 
concern over the unintentional consequences of antibiotic use. This review will discuss current understanding of these additional effects of antibiotics on the human microbiome, the resulting effects on health, and alternative therapeutic approaches.

\section{Approaches for identifying a dysbiotic microbiota}

It is becoming increasingly apparent that there exist several disease states for which a single causative pathogen has not been established. Rather, such diseases may be due to the abundances and relative amounts of a collection of microbes. Massively parallel sequencing technologies enable quick taxonomical surveys of an entire community by sampling genes from bacterial $16 \mathrm{~S}$ ribosomal DNA. In addition, to assess functional capability (i.e., the abundances and diversity of metabolic pathways or resistance genes), new computational tools can now analyze short reads from whole-metagenome shotgun sequencing, neatly sidestepping the challenges of read assembly from a complex and uncultured community [12-14]. These methods have been used extensively to establish baseline healthy microbiome compositions, which can then be statistically compared with samples from patients with a disease phenotype. In addition, machine learning algorithms such as random forests can be trained to discriminate between samples from healthy and dysbiotic microbiomes of individuals with a variety of health conditions. This approach ranks taxa in order of discriminatory power and outputs a predictive model capable of categorizing new microbiome samples as either healthy or diseased. Machine learning has been applied to discover which species are important to normal microbiome maturation [15], to malnutrition [16], to protection against cholera [17], and even to development of colon cancer [18]. In addition to high-throughput analysis of gene content, the use of metatranscriptomics [19], metaproteomics [20], and metametabolomics [21] to gain additional insight into the state of the microbiome in various disease contexts has been the focus of increasing interest. These applications underscore the importance of an ecosystem-level view of the gut microbiota in the context of disease diagnosis and therapeutic development.

\section{The effect of antibiotics on the microbiome in health and disease}

Development and maturation of the microbiome

As a child grows, the commensal microbiota develops in a predictable succession of species that is generalizable across human populations [15]. The developing bacteriome, the bacterial component of the microbiome, has been profiled many times, both taxonomically and in terms of metabolic functions $[15,22,23]$. These profiles have provided a view of how bacterial species are structured over time. Less is known about the gut-associated eukaryotes and viruses that develop along with the bacteriome, although they are an important part of the gut ecosystem [24, 25]. The disruption of the bacterial succession can be pathogenic [4-7]. Critical developmental milestones for the microbiota (as well as for the child) occur, in particular, during infancy and early childhood, and both medical intervention and lack of such intervention during these periods can have lifelong consequences in the composition and function of the gut ecosystem (Fig. 1). In this section, we discuss the instances in which antibiotics are often used during development and adulthood, the effects of antibiotics on the microbiota, and the implications of such effects for health and disease.

\section{Birth}

A child's first contact with microbes is usually assumed to occur after the rupture of the sterile amniotic sac. However, the placenta and the first stool of infants have been found to contain a full complement of microbes

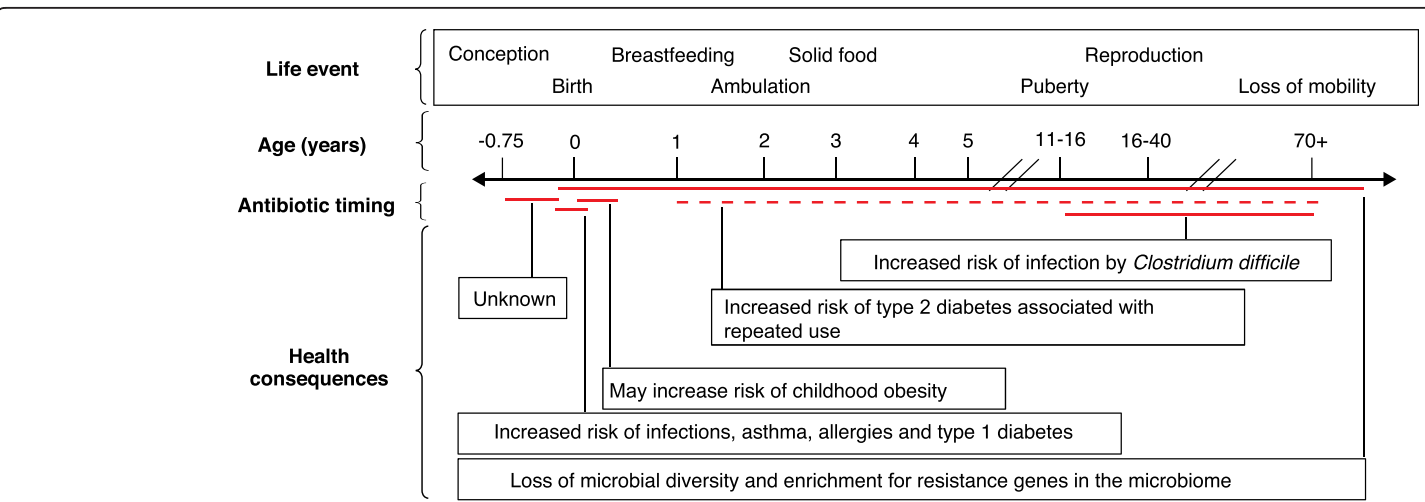

Fig. 1 Health consequences linked to the disruption of human-associated microbiota involving antibiotic use during development and adulthood. Red lines indicate that a single dose of antibiotics within the time period has been linked to a health consequence, whereas a dotted red line indicates that multiple doses of antibiotics within the time period are required to observe a link 
$[26,27]$ and a labeled strain of Enterococcus faecium has been shown to cross the umbilical cord in mice [28, 29]. These findings indicate that the first human-microbial interaction occurs before birth, although the effects of this interaction are unknown. Elucidating the function of a prenatal microbiome is especially important; for example, the majority of women in the USA are prescribed antibiotics during pregnancy and delivery [30] and at least 11 types of broad-spectrum antibiotics cross the placenta and reach the fetus [31].

Although the effects of prenatal antibiotics on neonates remain unclear, the microbes that first colonize a child after birth are known to have a fundamental influence on the development of the microbiome. An infant's mode of delivery is a critical determinant of the composition of their gut microbiota. During vaginal delivery, infants are colonized by the mothers' vaginal microflora (which is largely composed of Lactobacillus, Prevotella, and Sneathia species), whereas a Caesarean delivery omits transmission of vaginal microbes. Instead, the first microbes colonizing an infant delivered by Caesarean section are of environmental origin and generally associated with the skin (such as Staphylococcus, Corynebacterium, and Propionibacterium species) [32]. Intestinal strains of Bifidobacterium spp. have been shown to be transmitted vertically with vaginal but not Caesarean delivery [33]. Antibiotics are also routinely administered perinatally during Caesarian sections, which is a confounder in these analyses, although it is possible to delay the use of antibiotics until after umbilical clamping, thus separating the effect of antibiotics used by the mother from the effects of those used by the infant. The effects of perinatal administration of antibiotics are likely to further distinguish the microbiota composition of infants delivered by Caesarian section from that of infants delivered vaginally. Postnatal antibiotics can also irreversibly disrupt the natural microbiome succession, as an infant is unlikely to be recolonized with a second dose of vaginal microbes. The composition of the gut microbiome of infants born by Caesarean section has been directly linked with increased susceptibility to, and frequency of infection by, methicillin-resistant Staphylococcus aureus (MRSA) [34], which is a symptom of instability and low diversity in the gut ecosystem. Caesarean sections are also associated with a variety of long-term health problems, especially immunological disorders such as asthma [35] and type 1 diabetes [36, 37]. Therefore, elucidating the relationships between these disorders and the composition of the gut microbiome is critical to understanding the risks associated with antibiotic intervention in infants.

Premature birth (birth at $<33$ weeks of gestation) also has a major influence on the gut microbiome and results in a much greater prevalence of Proteobacteria than that usually seen in the Firmicute-dominated microbiota of infants born at full term [38]. This trend is aggravated by the aggressive regimen of broad-spectrum antibiotics given to premature infants (generally ampicillin and gentamicin), whose frequency and dosage is usually limited only by the toxicity of the drugs being used (Table 1). Extended antibiotic treatment ( $>5$ days) in premature infants is associated with an increased risk of late-onset sepsis (primarily caused by group B Streptoccoccus), necrotizing enterocolitis, and overall mortality [39, 40]. Antibiotic use further shifts the composition of the gut microbiota toward an increased abundance of Proteobacteria by depressing Bifidobacterium populations [41]. More generally, bacteriocidal drugs decrease the overall diversity of the infants' gut microbiota and select for drug-resistant microbes [42, 43]. Alternative strategies are needed to prevent and treat infections in premature infants.

\section{Early childhood}

The effects of antibiotics on microbial succession, diversity, and resistance can last long past infancy. In the first two or three years of life, a healthy child's microbiome increases in diversity to resemble an adult microbiome [15]. Bacteriophage (phage) titers start high and drop over time, while eukaryotic viruses are acquired from the environment and accumulate [24]. During this period, microbes are continuously obtained from breast milk, other food, and the environment [44]. When the developmental trajectory of the microbiome is altered by modifying factors, the digestive function can be negatively affected, which can result in either undernutrition or obesity. These phenotypes are often found in underdeveloped and developed countries, respectively. The undesirable microbiome configurations associated with undernutrition and obesity are shaped via selection by diet (calorie restriction or a high-calorie, low-quality diet, respectively) [45], by exposure to disease (high frequency of diarrhea or excessive hygiene) [46], and by the use of medications such as antibacterial agents [47].

Severe calorie restriction during the first years of life has devastating long-term consequences, including damage to learning ability, physical stunting, and diminished economic productivity in the survivors [48]. Undernutrition has a distinct microbial signature consistent with a delay in developmental progression of the microbiome. In Bangladesh, this signature consists of a delay of maturation, which is typically characterized by lower abundances of Bifidobacterium longum and increased abundances of Faecalibacterium prasunitzii, Lactobacillus ruminis, and Dorea longicatena [16]. This immature microbiome state is associated with inefficient nutrient extraction from food and vulnerability to enteric infections, which perpetuate the malnourished state and often 
Table 1 Main antibiotics used for pediatric or adult infections that modify the microbiome

\begin{tabular}{|c|c|c|c|c|c|c|c|}
\hline Antibiotic & $\begin{array}{l}\text { Molecular } \\
\text { target }\end{array}$ & Class & $\begin{array}{l}\text { Resistance } \\
\text { mechanism }\end{array}$ & Effect on gut microbiota & Effect on gut transcriptome & Effect on gut proteome & Effect on gut metabolome \\
\hline Amoxicillin & Transpeptidase & $\beta$-lactam & $\begin{array}{l}\text { Altered target, } \\
\beta \text {-lactamase }\end{array}$ & $\begin{array}{l}\text { Reduced abundance } \\
\text { enterobacteria [167] }\end{array}$ & NA & NA & NA \\
\hline Ampicillin & Transpeptidase & $\beta$-lactam & $\begin{array}{l}\text { Altered target, } \\
\beta \text {-lactamase }\end{array}$ & $\begin{array}{l}\text { Decreased bacterial diversity, } \\
\text { greater prevalence of } \\
\text { Enterobacter spp. [42] }\end{array}$ & $\begin{array}{l}\text { Increased expression of genes } \\
\text { involved in tRNA biosynthesis, } \\
\text { translation, vitamin } \\
\text { biosynthesis, phosphate } \\
\text { transport, stress response, } \\
\text { proton motive force, antibiotic } \\
\text { resistance and phage [72]; } \\
\text { reduced immune cell and } \\
\text { mitochondrial gene } \\
\text { expression [19] }\end{array}$ & $\begin{array}{l}\text { Increased bacterial } \\
\text { glycosidase and mucinase } \\
\text { activity [168] }\end{array}$ & NA \\
\hline Cefotaxime & Transpeptidase & $\begin{array}{l}\text { B-lactam (third } \\
\text { generation } \\
\text { cephalosporin) }\end{array}$ & Altered target & $\begin{array}{l}\text { Decreased bacterial cell count } \\
\text { [169]; decreased abundance of } \\
\text { anaerobes and enterobacteria } \\
{[170]}\end{array}$ & NA & NA & NA \\
\hline Chloramphenicol & NA & NA & NA & NA & $\begin{array}{l}\text { Increased expression of genes } \\
\text { involved in tRNA biosynthesis, } \\
\text { translation, vitamin } \\
\text { biosynthesis, phosphate } \\
\text { transport, stress response, } \\
\text { proton motive force, antibiotic } \\
\text { resistance and phage [72] }\end{array}$ & NA & NA \\
\hline Ciprofloxacin & DNA gyrase & Fluoroquinolone & $\begin{array}{l}\text { Altered target, } \\
\text { efflux }\end{array}$ & $\begin{array}{l}\text { Decreased abundance of } \\
\text { enterobacteria [171]. Lower } \\
\text { bacterial diversity [68, 69], } \\
\text { decrease in short-chain fatty } \\
\text { acid (SCFA) producers [71] }\end{array}$ & $\begin{array}{l}\text { Increased expression of genes } \\
\text { involved in tRNA biosynthesis, } \\
\text { translation, vitamin } \\
\text { biosynthesis, phosphate } \\
\text { transport, stress response, } \\
\text { proton motive force, antibiotic } \\
\text { resistance and phage [72] }\end{array}$ & NA & NA \\
\hline $\begin{array}{l}\text { Clarithromycin } \\
\text { plus } \\
\text { metronidazole }\end{array}$ & $\begin{array}{l}\text { Bacterial } 505 \\
\text { rRNA/DNA } \\
\text { synthesis }\end{array}$ & $\begin{array}{l}\text { Macrolide } \\
\text { (clarithromycin) } \\
\text { and } \\
\text { nitroimidazole } \\
\text { (metronidazole) }\end{array}$ & $\begin{array}{l}\text { Altered target/ } \\
\text { drug } \\
\text { inactivation } \\
\text { (clarithromycin) } \\
\text { and efflux } \\
\text { (metronidazole) }\end{array}$ & $\begin{array}{l}\text { Reduction in abundance of } \\
\text { Actinobacteria, partial recovery } \\
\text { of pretreatment state [70] }\end{array}$ & NA & NA & NA \\
\hline
\end{tabular}

stress response

tive force antibiotic

ncreased expression of genes NA

nvolved in tRNA biosynthesis,

slation, vitamin

decrease in short-chain fatty

(metronidazole) 
Table 1 Main antibiotics used for pediatric or adult infections that modify the microbiome (Continued)

\begin{tabular}{|c|c|c|c|c|c|c|c|}
\hline Clindamycin & $\begin{array}{l}\text { Bacterial } 50 S \\
\text { rRNA }\end{array}$ & Lincosamide & Altered target & $\begin{array}{l}\text { Initial decreased abundance of } \\
\text { enterococci, streptococci, and } \\
\text { anaerobic bacteria, } \\
\text { subsequent recovery of } \\
\text { abundance of streptococci } \\
\text { and anaerobic bacteria [172]; } \\
\text { reduced diversity of } \\
\text { Bacteroides spp. [74]; decrease } \\
\text { in abundance of bacteria } \\
\text { producing short-chain fatty } \\
\text { acids [71] }\end{array}$ & NA & $\begin{array}{l}\text { Increased production of } \\
\text { immunoglobulin proteins, } \\
\text { transthyretin and } \\
\text { chymotrypsin-like elastase } \\
\text { family proteins; decreased } \\
\text { production of proteins } \\
\text { involved in T-cell activation, } \\
\text { chymotrypsinogen B, } \\
\text { phospholipase A2, } \\
\text { myosin-1a and cytochrome } \\
\text { C [20] }\end{array}$ & $\begin{array}{l}\text { Increased creatine and } \\
\text { creatinine, and levels of primary } \\
\text { bile acids, N-acetylated amino } \\
\text { acids, proline-hydroxyproline, } \\
\text { pyroglutamylglutamine, } \\
\text { myo-inositol, chiroinositol, } \\
\text { methyl-chiro-inositol and } \\
\text { Y-glutamyl amino acids, and } \\
\text { increased host tryptophan } \\
\text { metabolism; decreased levels } \\
\text { of secondary bile acids, } \\
\text { enterolactone, equol, } \\
\text { N-acetyl-aspartate, short-chain } \\
\text { fatty acids and sugar alcohols, } \\
\text { and decreased bacterial } \\
\text { tryptophan metabolism [84] }\end{array}$ \\
\hline Erythromycin & Translation & Macrolide & Efflux & $\begin{array}{l}\text { Decreases in abundance of } \\
\text { Streptococci, enterococci, and } \\
\text { enterobacteria; increases in } \\
\text { abundance of staphylococci; } \\
\text { alteration in abundance of } \\
\text { anaerobes [173] }\end{array}$ & $\begin{array}{l}\text { Increased expression of genes } \\
\text { involved in tRNA biosynthesis, } \\
\text { translation, vitamin } \\
\text { biosynthesis, phosphate } \\
\text { transport, stress response, } \\
\text { proton motive force, antibiotic } \\
\text { resistance, and phage [72] }\end{array}$ & NA & NA \\
\hline Gentamicin & $\begin{array}{l}\text { Bacterial } 305 \\
\text { ribosome }\end{array}$ & Aminoglycoside & $\begin{array}{l}\text { Decreased } \\
\text { uptake, drug } \\
\text { modification }\end{array}$ & $\begin{array}{l}\text { Decreased bacterial diversity, } \\
\text { greater prevalence of } \\
\text { Enterobacter spp. [42] }\end{array}$ & NA & NA & $\begin{array}{l}\text { Increased levels } \\
\text { ofoligosaccharides and } \\
\text { secondary bile acids; decreased } \\
\text { levels of short-chain fatty acids, } \\
\text { phenolic acids, uracil, primary } \\
\text { bile acids, branched-chain } \\
\text { amino acids and aromatic } \\
\text { amino acids [85] }\end{array}$ \\
\hline Meropenem & Transpeptidase & Carbapenem & $\begin{array}{l}\text { Altered target, } \\
\beta \text {-lactamase }\end{array}$ & $\begin{array}{l}\text { Reduced abundance of } \\
\text { enterobacteria, streptococci, } \\
\text { Clostridia, Bacteroides spp., and } \\
\text { Gram-negative cocci [174] }\end{array}$ & NA & NA & NA \\
\hline Streptomycin & $\begin{array}{l}\text { Bacterial } 305 \\
\text { ribosome }\end{array}$ & Aminoglycoside & $\begin{array}{l}\text { Decreased } \\
\text { uptake, drug } \\
\text { modification }\end{array}$ & $\begin{array}{l}\text { Overall diversity decreases; } \\
\text { abundance of } \\
\text { Ruminococcaceae and } \\
\text { Bacteroidaceae increases [20] }\end{array}$ & NA & $\begin{array}{l}\text { Increased production of } \\
\text { peptidases, proteins involved } \\
\text { in actin polymerization, } \\
\text { transthyretin, chymotrypsin-like } \\
\text { elastase family proteins, } \\
\text { myosin-1a, and cytochrome C; } \\
\text { decreased production of } \\
\text { chymotrypsinogen B and } \\
\text { phospholipase A2 [20] }\end{array}$ & $\begin{array}{l}\text { Bile acid metabolism, steroid } \\
\text { metabolism, and eicosanoid } \\
\text { synthesis affected; levels of } \\
\text { leukotriene } B_{4} \text { decrease [88] }\end{array}$ \\
\hline
\end{tabular}
greater prevalence of uptake, drug modification

Altered target 
Table 1 Main antibiotics used for pediatric or adult infections that modify the microbiome (Continued)

\begin{tabular}{|c|c|c|c|c|c|c|c|}
\hline Ticarcillin & Transpeptidase & $\beta$-lactam & $\begin{array}{l}\text { Altered target, } \\
\beta \text {-lactamase }\end{array}$ & $\begin{array}{l}\text { Decreased abundance of } \\
\text { enterococci [175] }\end{array}$ & NA & NA & NA \\
\hline Tigecycline & $\begin{array}{l}\text { Bacterial } 30 S \\
\text { ribosome }\end{array}$ & Tetracycline & $\begin{array}{l}\text { Altered target, } \\
\text { efflux }\end{array}$ & $\begin{array}{l}\text { Reduction in abundance of } \\
\text { enterococci, E. coli, lactobacilli, } \\
\text { and bifidobacteria and } \\
\text { increases in other } \\
\text { enterobacteria and yeasts } \\
\text { [176]; reduction in abundance } \\
\text { of Bacteroidetes and increases } \\
\text { in Proteobacteria [81] }\end{array}$ & NA & NA & NA \\
\hline Vancomycin & Peptidoglycan & Glycopeptide & $\begin{array}{l}\text { Altered } \\
\text { peptidoglycan } \\
\text { target }\end{array}$ & $\begin{array}{l}\text { Decreased bacterial diversity } \\
{[177]}\end{array}$ & $\begin{array}{l}\text { Increased expression of genes } \\
\text { involved in tRNA biosynthesis, } \\
\text { translation, vitamin } \\
\text { biosynthesis, phosphate } \\
\text { transport, stress response, } \\
\text { proton motive force, antibiotic } \\
\text { resistance, and phage [72]; } \\
\text { reduced immune cell and } \\
\text { mitochondrial gene } \\
\text { expression [19] }\end{array}$ & NA & $\begin{array}{l}\text { Leukotriene } B_{4} \text { affected [88]; } \\
\text { increased levels of } \\
\text { oligosaccharides and } \\
\text { decreased levels of } \\
\text { short-chain fatty acids and } \\
\text { uracil [86]; low doses increase } \\
\text { levels of short-chain fatty } \\
\text { acids [53] }\end{array}$ \\
\hline
\end{tabular}


make nutritional therapy ineffective [49]. Intriguingly, a week-long course of either amoxicillin or cefdinir has been found to improve nutritional recovery and reduce mortality associated with severe acute malnutrition [50]. The combination of antibiotics and nutritional therapy has become standard of care in outpatient management of severe acute malnutrition [51]. The growth response of malnourished patients to therapeutic-dose antibiotics parallels the phenomenon where increased growth is observed in animals given continuous, low-dose, broadspectrum antibiotics [52]. This effect, as well as more subtle metabolic shifts toward adiposity, has been reproduced in mice [53]. Children from low-income countries also show increased weight gain after antibiotic therapy even when they are not clinically malnourished [54]. More research is needed to establish the mechanisms underlying this treatment and to quantify its repercussions in terms of antibiotic resistance.

On the other hand, obesity has grown to epidemic proportions in developed countries. In 2015, over $30 \%$ of adults and $17 \%$ of children in the USA were estimated to have obesity $[55,56]$. The contributions of diet and lifestyle to weight gain are well publicized, but the role of the gut microbes has only recently come to light. A high-calorie diet shifts the microbial ecology toward Firmicutes at the expense of Bacteroidetes, thus increasing the energy harvesting capacity of the microbiota [57]. Microbes from obesity-discordant twins can reproduce the respective phenotypes in gnotobiotic mice [58,59], which indicates a causal role for the microbiota in obesity. Antibiotic exposure during infancy has been found to increase the risk of overweight in preadolescence for boys [47], although this association was not found in a different population. Similarly, the risk of developing type 2 diabetes increases with repeated use of penicillins, macrolides, cephalosporins, and quinolones [60, 61]. This association could be confounded by the increased susceptibility of people with diabetes to infections requiring antibiotic treatment; however, this possibility is countered by the fact that antifungals and antivirals, which are also more frequently sought by these patients, do not increase the risk of developing diabetes [61]. These findings support the notion that the bacteriome has a strong but uncharacterized role in metabolic disease. Further research is critical to understand the mechanisms underlying these nutritional and metabolic health effects of the bacteriome. This understanding will promote rational and frugal antibiotic use to prevent microbiome disruption and enable the restoration of the microbiota after antibiotic use.

\section{Adulthood}

The mature adult microbiome has been assessed across many populations. The largest project in this area to date is the Human Microbiome Project, which assessed
15-18 body sites in 242 participants in 2012 and continues to sample new individuals [62]. An important finding from this project was that microbial populations differ substantially among healthy individuals, and so far no single microbial composition has been defined as healthy, aside from a preponderance of Bacteroidetes and Firmicutes. General trends observed in follow-up studies include a decrease in microbiome diversity in developed countries compared with the diversity found in hunter-gatherers or societies with restricted access to Western medicine $[63,64]$. This difference is often attributed to the hygiene hypothesis, which in addition to improved cleanliness points to the overuse of antibiotics during infections as causal to a reduced microbiome diversity in developed countries. A large range of antibiotics has indeed been shown to transiently or permanently alter the composition of healthy adult microbiotas, usually via depletion of one or several taxa (Table 1). Importantly, the effects of an antibiotic on a microbial community in vivo are likely to be depend on the phylogenetic composition of the community and are not predictable on the basis of the susceptibilities of isolated members of the community to antibiotics observed in vitro. Predicting the effects of antibiotics is complicated by the widely varying concentration of the drug across the body, different microbial growth stages [65], antibiotic-associated induction of phages, interdependence among microbial taxa, and the existence of "cheaters", or susceptible microbes that are protected by extracellular resistance enzymes produced by other microbes [66]. Repeated empirical measurements of the effects of an antibiotic on a microbial community are therefore the best way to predict how a particular gut microbiome will respond to a given antibiotic.

Oral amoxicillin exposure caused marked shifts in microbiome composition that lasted approximately 30 days on average and were observed for more than 2 months in some of the treated individuals [67]. Large shifts were also reported during an oral course of ciprofloxacin, with the changes persisting for several weeks; the extent of restoration of the baseline composition of the microbiome was highly subject-dependent $[68,69]$. A similar subject-dependence in the composition of the microbiome after antibiotic therapy was also observed with cefprozil [63]. The effect of antibiotics also differs by body site, with the throat and saliva recovering their initial microbial diversity after antibiotic therapy much more quickly than the gut $[70,71]$. In addition to their effect on the phylogenetic makeup of the microbiome, antibiotics select for resistance in the surviving gut microbiota by stimulating the expression of antibiotic resistance, stress response, and phage genes [72] (Table 1), as well as by increasing the abundance of the resistance genes themselves [73, 74]. 
These mobilized resistance genes are a reservoir for drug resistance in pathogens [75].

There are multiple and poorly understood interactions between the microbiome and immune system. Failure to regulate immune responses to benign organisms is a common one. Antibiotics interfere with the interaction between the microbiome and immune system, resulting in immunological disorders [35, 76]; antibiotics also increase the host's susceptibility to pathogens $[34,46,77$, 78] (Table 2). Indeed, antibiotics have been shown to alter the transcriptome and proteome of host tissues $[19,20]$ (Table 1). Perturbations in the host proteome followed a different timescale than perturbations in the species content of the microbiome, with the streptomycin-altered proteome recovering before the microbiota but the clindamycin-perturbed proteome remaining perturbed after microbiota recovery [20]. In an elegant study by Morgun et al. [19], the effects of antibiotics on the host transcriptome were classified by their major cause. The reduction in the number of bacteria in general caused a decrease in gene expression in immune cells, whereas the presence of antibiotics and a prevalence of antibioticresistant bacteria together caused a reduction in mitochondrial gene expression and in the number of mitochondria per cell. Although the ability of antibiotics to affect mitochondria (which is due to the bacterial origin of these organelles) was previously known, the researchers identified the virulence-associated molecular pathways of Pseudomonas aeruginosa as important drivers of mitochondrial gene loss and host cell death in this study. These and other findings clearly show that antibiotics, alone and through their effects on the gut microbiota, have important effects on host gene expression.

The majority of studies investigating the effects of antibiotics on the gut metabolome have been focused on susceptibility to infection, most notably with Clostridium difficile and Salmonella typhimurium. The number of deaths associated with $C$. difficile infection reaches 14,000 per year [79]. Infected patients receive high-dose, extended-duration treatment with multiple antibiotics, yet nevertheless up to $65 \%$ of patients relapse [80]. Recurrence of $C$. difficile-associated diarrhea is associated with a low-diversity microbiome [77]. Exposure to either clindamycin or tigecycline decreases microbiome diversity and increases susceptibility to $C$. difficile infection $[78,81]$. Similarly, streptomycin and vancomycin use has been shown to cause an increased susceptibility to $S$. typhimurium infection [46]. The release of sugars and bile acids due to antibiotic-induced depletion of the metabolic activities of gut commensals has been proposed as a potential mechanism for this effect $[82,83]$. These nutrients provide an ecological niche that can be exploited by pathogens. Multiple studies in which high-throughput metabolomics was performed on an antibiotic-treated microbiome have shown that high concentrations of antibiotics reduce or eliminate most products of bacterial metabolism (including shortchain fatty acids and secondary bile acids), whereas their precursors (including oligosaccharides, sugar alcohols, and primary bile acids) build up [21, 84-87]. In addition, several compounds of the bile acid, steroid, and tryptophan metabolic pathways were significantly altered by antibiotic treatment $[88,89]$ (Table 1$)$. These metabolic effects seem to be independent of antibiotic class and rather depend on antibiotic concentration, as subtherapeutic doses of penicillin, vancomycin, penicillin plus vancomycin, or chlortetracycline actually increase the concentration of short-chain fatty acids [53]. Multiple metabolic routes exist for $C$. difficile to exploit following antibiotic treatment. In particular, antibiotics deplete the bile acid-hydroxylating activity of Clostridium scindens, which is required for protection

Table 2 Examples of antibiotic-induced changes in microbiota that lead to disease

\begin{tabular}{|c|c|c|}
\hline Feature & Effect of antibiotics & Pathological consequence \\
\hline $\begin{array}{l}\text { Antibiotic } \\
\text { resistance }\end{array}$ & $\begin{array}{l}\text { Enrichment for resistance genes and resistant organisms [73]. In } \\
\text { some cases, the rates of genetic exchange between microbes } \\
\text { increase [178] }\end{array}$ & $\begin{array}{l}\text { Multidrug-resistant tuberculosis. Carbapenem-resistant Escherichia } \\
\text { coli infection [79] }\end{array}$ \\
\hline $\begin{array}{l}\text { Vitamin } \\
\text { production }\end{array}$ & Depletion of vitamin-producing bacteria & $\begin{array}{l}\text { Broad-spectrum antibiotic use (especially } \beta \text {-lactams with an } \mathrm{N} \text { - } \\
\text { methylthiotetrazole moiety) can cause vitamin K deficiency leading } \\
\text { to hypoprothrombinemia and uncontrolled bleeding [179] }\end{array}$ \\
\hline Digestion & $\begin{array}{l}\text { Changes in the proportions of relevant metabolic functions in } \\
\text { the microbiome [180] }\end{array}$ & $\begin{array}{l}\text { Altered efficiency of nutrient extraction from food that can } \\
\text { contribute to obesity }[45,59]\end{array}$ \\
\hline Diversity & Reduced number of different microbes [68] & $\begin{array}{l}\text { Lower diversity reduces ecological stability and resistance to } \\
\text { pathogens. Increased susceptibility to infection and diarrhea } \\
{[34,46,77,78]}\end{array}$ \\
\hline Resilience & $\begin{array}{l}\text { Decreased availability of microbes to take over newly open } \\
\text { niches }\end{array}$ & $\begin{array}{l}\text { Each course of antibiotic acts on a new ecology. Recovery to a } \\
\text { stable state, and to a particular stable state, is highly individual [63] }\end{array}$ \\
\hline $\begin{array}{l}\text { Immune } \\
\text { regulation }\end{array}$ & Increased inappropriate immune activity & $\begin{array}{l}\text { Asthma, allergies and autoimmune diabetes have all been linked to } \\
\text { antibiotic use }[6,10,61]\end{array}$ \\
\hline Composition & Varying effects across taxa and for different durations & See Table $1[41,67-69,72]$ \\
\hline
\end{tabular}


against $C$. difficile infection [90]. As an additional mechanism promoting infection, antibiotics may enhance bacterial translocation out of the gut [91]. These findings show that provision of broad-spectrum antibiotics can be counterproductive in the treatment of recalcitrant, antibiotic-resistant infections. Alternative strategies such as fecal microbiota transplants (FMTs), which are discussed below, have been used to treat $C$. difficile with a cure rate higher than $90 \%$ [92].

\section{Alternative approaches for modulating the gut microbiota \\ Targeting pathogens while maintaining a healthy microbiota}

The examples highlighted above make it clear that overuse of antibiotics can often have negative effects on the host through collateral damage to commensal microbes. As an alternative to broad-spectrum drugs, the development of narrow-spectrum treatments that specifically reduce the capacity of pathogens to cause disease while leaving commensals unharmed has been the focus of increasing interest. The enormous variety of existing antivirulence strategies is briefly summarized here. A more complete discussion of antivirulence therapeutics can be found elsewhere [93-96].

\section{Anti-quorum sensing}

Quorum sensing (QS) is the mechanism by which bacteria coordinate behavior as a function of population density. The concentration of a continuously secreted signaling molecule serves as a marker of local population size and virulence programs are upregulated or downregulated as a function of this concentration [97]. QS plays a critical part in the virulence of many pathogens, including Vibrio cholerae and P. aeruginosa [98]. QS can be pharmacologically inhibited in a variety of ways, including destruction of the QS signal [99], acceleration of turnover of key QS proteins [100-102], and competition with the QS signal for binding to key regulatory proteins [103-105]. However, P. aeruginosa variants resistant to such quorum-quenching drugs have been recently identified [106, 107] and development of this resistance is thought to be caused by a selective disadvantage in those bacteria lacking QS machinery, even when an infection is not occurring [108]. These observations underscore the risks of having an anthropocentric view of "virulence" pathways and highlight a need for holistic understanding of the roles of such pathways within the cell to develop robust antivirulence strategies.

\section{Anti-toxin production}

Toxin production is critical to the virulence of a wide variety of species. Small-molecule inhibitors of C. difficile major virulence factor toxin B [109], Bacillus anthracis lethal factor [110], B. anthracis protective antigen channel [111], and Escherichia coli verotoxin [112] have been developed as a countermeasure to the activity of these bacterial toxins. Taking inspiration from the body's own defense repertoire and the historical use of antisera against bacterial infections [113], antibodies against Shiga [114, 115] and anthrax [116] toxins have also been developed. Small-molecule inhibitors of ToxT, the transcription factor controlling the production of cholera toxin, have been shown to be effective in mouse models, though associated with the development of resistance [117, 118]. Finally, inhibitors of type 2, [119], type 3 [119-125], and type 4 [126] secretion systems have been identified, which collectively inhibit the virulence of Yersinia pseudotuberculosis, Chlamidophila pneumoniae, Chlamidia trachomatis, Shigella flexneri, S. typhimurium, E. coli, and Brucella spp. Whether inhibition of toxin production is a stable strategy against virulence is unclear because although toxin producers are at an increased metabolic burden relative to nonproducers when the toxin is ineffective, this environment provides a strong selective pressure for anti-toxin-resistant mutants or even for mutants that overexpress the toxin [108].

\section{Other antivirulence strategies}

Pilus formation is critical to the adherence of uropathogenic $E$. coli to host cell tissue and several compounds that inhibit pili (pilicides) have been effective against this strain [127-130]. Carotenoid production is important to the removal of host reactive oxygen species by Staphylococcus aureus and inhibitors of carotenoid production reduce the virulence of this organism [131]. The production of biofilms is important to the virulence of several pathogens and also interferes with the delivery of antibiotics to their target site. Anti-biofilm compounds, in addition to restricting virulence when used as monotherapy [132], could be used in conjunction with broadspectrum antibiotics or orthogonal antivirulence therapies. Finally, siderophores facilitate the scavenging of rare iron from the host environment and are therefore critical to the survival of several pathogens, including $P$. aeruginosa. Compounds that inactivate siderophores therefore represent an evolutionarily robust antivirulence strategy [133]. Taken together, antivirulence therapies are a promising alternative to traditional broad-spectrum drugs owing to reduction of potential off-target effects as well as reduction in the number of organisms under pressure to develop resistance, even if the ideal "evolution-proof" therapy has not been found.

\section{Restoring or enhancing the microbiota}

In contrast to approaches focused on targeting certain members of the gut microbiota, strategies have been 
developed to prevent enteric infections through the delivery of additional or replacement species to the gut to increase its resilience to infection. These strategies include the use of probiotics, fecal microbiota transplants, and phage therapy.

\section{Probiotics}

Probiotics are defined as "live microorganisms which when administered in adequate amounts confer a health benefit on the host" [134]. Probiotics are often seen as an approach to restore or improve a dysbiotic microbiota [135] and are an effective treatment for a wide range of gastrointestinal diseases, including $C$. difficile infection [136], antibiotic-associated diarrhea [137-139], and acute infectious diarrhea [140]. Lactobacillus species are used as probiotics [141], with $L$. salivarius being effective against Listeria infection [142] and $L$. reuteri being preventive against antibiotic-associated diarrhea [143]. In addition, Bifidobacterium animalis has been shown to protect against infections in infants [144] and E. coli Nissle, in addition to being an effective treatment for Crohn's disease and inflammatory bowel disease [145], has been shown to reduce enteric counts of multidrug-resistant E. coli [146]. Most meta-analyses of probiotic use agree that while probiotics can be effective against a range of gut dysbioses, more specific data are needed to determine which probiotics are best for particular patient groups, especially as extensive interindividual variation exists in the composition of gut microbiota.

Advances in genetic engineering have fueled a growing interest in augmenting the gut microbiota with engineered strains to expand gut function or resilience beyond what can be achieved by administration of unmodified strains. Engineered Lactococcus lactis has been used to express and deliver antimicrobial peptides against $E$. faecium, reducing pathogen counts by 10,000 fold in vitro [147]. Excitingly, a recombinant invasive strain of L. lactis was used to transfect host cells with engineered DNA in vivo, which led to stimulation of tuberculosis antigen production in mice [148]. Additionally, "sense and destroy" probiotics, which encode sensors for biomarkers of pathogenic strains, have been developed. Upon detection of a pathogen, these probiotics activate a genetic program to kill their target. Two recent studies engineered probiotics to detect 3-acyl-homoserine lactone (used in QS) to specifically target $P$. aeruginosa. Pathogen killing was mediated by expression of engineered antimicrobial peptides in one instance [149] and by increased motility and expression of biofilm degradation enzymes and antimicrobial peptides in the second [150]. Such "smart" therapeutics promise to reduce the development of resistance and off-target effects by restricting treatment to strains of interest in a time-specific and space-specific manner. However, production of killing compounds is not the only mechanism by which engineered probiotics can ward off infections. Increased understanding of nutrient resource (e.g., carbohydrate) utilization within the gut is enabling the development of strains that can outcompete pathogens when available metabolic niches are colonized [82, 151]. Although substantial challenges regarding the safety, containment, and consumer acceptance of engineered probiotics remain to be fully addressed, the therapeutic potential of probiotics enabled by genetic engineering of the gut microbiome is enormous.

\section{Fecal microbiota transplants}

For opportunistic, antibiotic-resistant infections such as C. difficile infections, alternative therapies to antibiotics are far superior to antibiotic-based approaches [152, 153]. The transfer of fecal microbes from a healthy person to a patient has been used as a remedy for recurrent diarrhea for at least 1700 years [154]. This approach is the most comprehensive and crude form of probiotic therapy, as an entire balanced community is administered at once, without necessarily knowing which components are valuable. Healthy fecal microbes are thought to suppress $C$. difficile blooms through niche competition and, potentially, through the production of yet unidentified growth inhibitors. In the near term, FMTs might become a critical tool to limit the spread of antibiotic resistance and lengthen the time to obsolescence for remaining viable antibiotics. In the future, FMTs might be replaced by defined preparations of their constituent therapeutic factors as detailed knowledge of the ecology of the gut microbiota increases.

\section{Phage therapy}

In addition to its bacterial inhabitants, the gut contains an equally fascinating viral community that exerts a profound effect on the microbiota and, in turn, on the host. As the natural predators of bacteria, phages were used to treat bacterial infections before the advent of antibiotics, after which the use of phage therapy was restricted to the USSR [155]. As antibiotics have become less effective, phages have been the focus of renewed therapeutic interest as they are often highly specific to their target bacteria (which reduces off-target effects on the rest of the microbiota) and are self-replicating (which reduces the costs of producing phage-based therapeutics relative to the costs of producing small-molecule therapeutics and also enables co-evolution of the therapies and their pathogen targets). Phages active against $E$. faecalis [156], Bacillus cereus [157], and P. aeruginosa [158] have been identified, among many others. As is the case for antibiotics, the development of resistance to phages is evolutionarily favorable, but phage-resistant mutants have been observed to be less virulent than their phage- 
susceptible wild type for some bacteria/phage combinations $[159,160]$. Excitingly, phages have also been the subject of genetic engineering to improve their function in modulating the gut ecosystem [161]. In particular, the expression of a biofilm-degrading enzyme on the genome of T7 phages enabled simultaneous reduction of biofilm and bacterial lysis in a positive-feedback manner [162]. T7 phages have also been engineered to encode quorum-quenching enzymes as a defense against biofilm formation [163]. Recently, the natural transformation capacity of phages has been coupled with programmable nucleases to enable the generation of phages that specifically kill bacteria with undesirable genomic sequences, such as antibiotic resistance genes or virulence factors [164, 165]. By programming sequences from resistance genes and lytic phages as substrates for nucleases, Yosef et al. [166] generated a system with a positive selective pressure for loss of antibiotic resistance. On the basis of these reports, we envision that the first diseases for which phage therapy would be appropriate are those whose bacterial cause is well-defined, refractory to antibiotics, and accessible to phages, such as diseases caused by Mycobacterium tuberculosis, $V$. cholerae, $C$. difficile, enteroaggregative $E$. coli, and diffusely adherent E. coli. Although substantial hurdles involving resistance to both phages and engineered nucleases need to be cleared, natural and engineered phages hold great promise as future tools in the fight against pathogens and dysbiotic community states.

\section{Conclusions and future directions}

Antibiotics shape the ecology of the gut microbiome in profound ways, causing lasting changes to developing and mature microbiotas. The application of nextgeneration sequencing has enabled detailed views of the side effects these drugs have on commensal populations during treatment of infections. In addition to the increased threat of resistance to antibiotics caused by the overuse of these compounds, these important side effects make it clear that overuse of broad-spectrum antibiotics must be quickly phased out in favor of more precise approaches and must be complemented by efficient methods to restore the microbiome after injury. Fortunately, recent advances in the development of narrow-spectrum antivirulence compounds, coupled with a renewed interest in the use of probiotics, FMTs and phage therapy, bring new hope to defeating diseasecausing bacteria while limiting collateral damage to the microbiota. Looking ahead, we anticipate that individualized ecological and metabolic models of the microbiome will have an important role in informing treatment options during dysbiosis, and that these treatment options will be expanded to include evolution-resistant antivirulence compounds, robust curated communities of healthy gut commensals, and "smart" living therapeutics that sense and respond to disease states with minimal patient and doctor intervention. Collectively, advancements in our understanding of the effects of antibiotics on gut commensals are leading to new insights into this complex and important microbial community and are driving new therapeutic strategies in our fight against pathogenic bacteria.

\section{Abbreviations}

FMT: fecal microbiota transplant; MRSA: methicillin-resistant Staphylococcus aureus; QS: quorum sensing.

\section{Competing interests}

The authors declare that they have no competing interests.

\section{Authors' contributions}

$\mathrm{AL}$ and NC performed literature searches and drafted and edited the manuscript. GD edited the manuscript and provided guidance. All authors read and approved the final manuscript.

\section{Acknowledgements}

AL is supported in part by a Clinical and Translational Science Award (CTSA) program of the National Center for Advancing Translational Sciences (NCATS) of the National Institutes of Health $(\mathrm{NIH})$, under award numbers UL1 TR000448 and TL1 TR000449. NC is supported in part by the Pediatric Gastroenterology Research Training Program of the $\mathrm{NIH}$, under award number T32 DK077653. This work was supported in part by the National Institute of General Medical Sciences (grant numberR01-GM099538) and the $\mathrm{NIH}$ Director's New Innovator Award (number DP2-DK-098089) to GD. The content is solely the responsibility of the authors and does not necessarily represent the official views of the NIH.

\section{Author details}

${ }^{1}$ Center for Genome Sciences, Washington University School of Medicine, Campus Box 8510, 4515 McKinley Research Building, St. Louis, MO 63108, USA. ${ }^{2}$ Clinical Research Training Center, Washington University School of Medicine, Campus Box 8051, 660 South Euclid Avenue, St. Louis, MO 63110-1093, USA. ${ }^{3}$ Department of Pathology \& Immunology, Washington University School of Medicine, Campus Box 8118, 660 South Euclid Ave, St. Louis, MO 63110, USA. ${ }^{4}$ Department of Biomedical Engineering, Washington University in Saint Louis, Campus Box 1097, 1 Brookings Drive, Saint Louis, MO 63130, USA. ${ }^{5}$ Department of Molecular Microbiology, Washington University School of Medicine, Campus Box 8230, 660 S. Euclid Ave, St. Louis, MO 63110, USA.

Published online: 13 April 2016

\section{References}

1. Kinch MS, Patridge E, Plummer M, Hoyer D. An analysis of FDA-approved drugs for infectious disease: antibacterial agents. Drug Discov Today. 2014;19:1283-7. doi:10.1016/j.drudis.2014.07.005.

2. Review on Antimibrobial Resistance. Antimicrobial resistance: tackling a crisis for the health and wealth of nations. 2014. http://amr-review.org/sites/ default/files/AMR\%20Review\%20Paper\%20-\%20Tackling\%20a\%20crisis\% 20for\%20the\%20health\%20and\%20wealth\%20of\%20nations_1.pdf. Accessed 5 Apr 2016.

3. Guarner F, Malagelada J-R. Gut flora in health and disease. Lancet. 2003;361:512-9. doi:10.1016/S0140-6736(03)12489-0.

4. Holmes E, Loo RL, Stamler J, Bictash M, Yap IKS, Chan Q, et al. Human metabolic phenotype diversity and its association with diet and blood pressure. Nature. 2008;453:396-400. doi:10.1038/nature06882.

5. Smith MI, Yatsunenko T, Manary MJ, Trehan I, Mkakosya R, Cheng J, et al. Gut microbiomes of Malawian twin pairs discordant for kwashiorkor. Science. 2013:339:548-54. doi:10.1126/science.1229000.

6. Stefka AT, Feehley T, Tripathi P, Qiu J, McCoy K, Mazmanian SK, et al. Commensal bacteria protect against food allergen sensitization. Proc Natl Acad Sci U S A. 2014;111:13145-50. doi:10.1073/pnas.1412008111.

7. Marchesi JR, Holmes E, Khan F, Kochhar S, Scanlan P, Shanahan F, et al. Rapid and noninvasive metabonomic characterization of inflammatory bowel disease. J Proteome Res. 2007;6:546-51. doi:10.1021/pr060470d. 
8. Hsiao EY, McBride SW, Hsien S, Sharon G, Hyde ER, McCue T, et al. Microbiota modulate behavioral and physiological abnormalities associated with neurodevelopmental disorders. Cell. 2013;155:1451-63. doi:10.1016/j. cell.2013.11.024.

9. Lewis JD, Chen EZ, Baldassano RN, Otley AR, Griffiths AM, Lee D, et al. Inflammation, antibiotics, and diet as environmental stressors of the gut microbiome in pediatric Crohn's disease. Cell Host Microbe. 2015;18:489-500. doi:10.1016/j.chom.2015.09.008.

10. Teo SM, Mok D, Pham K, Kusel M, Serralha M, Troy N, et al. The infant nasopharyngeal microbiome impacts severity of lower respiratory infection and risk of asthma development. Cell Host Microbe. 2015;17:704-15. doi:10.1016/j.chom.2015.03.008.

11. Cuthbertson L, Rogers GB, Walker AW, Oliver A, Green LE, Daniels TW, et al, Respiratory microbiota resistance and resilience to pulmonary exacerbation and subsequent antimicrobial intervention. ISME J. 2015. doi:10.1038/ismej. 2015.198.

12. Segata N, Waldron L, Ballarini A, Narasimhan V, Jousson O, Huttenhower C. Metagenomic microbial community profiling using unique clade-specific marker genes. Nat Methods. 2012;9:811-4. doi:10.1038/nmeth.2066.

13. Abubucker S, Segata N, Goll J, Schubert AM, Izard J, Cantarel BL, et al. Metabolic reconstruction for metagenomic data and its application to the human microbiome. PLoS Comput Biol. 2012;8:e1002358. doi:10.1371/ journal.pcbi.1002358.

14. Kaminski J, Gibson MK, Franzosa EA, Segata N, Dantas G, Huttenhower C. High-specificity targeted functional profiling in microbial communities with ShortBRED. PLoS Comput Biol. 2015;11:e1004557. doi:10.1371/journal.pcbi. 1004557.

15. Yatsunenko T, Rey FE, Manary MJ, Trehan I, Dominguez-Bello MG, Contreras $M$, et al. Human gut microbiome viewed across age and geography. Nature 2012:486:222-7. doi:10.1038/nature11053.

16. Subramanian S, Huq S, Yatsunenko T, Haque R, Mahfuz M, Alam MA, et al. Persistent gut microbiota immaturity in malnourished Bangladeshi children. Nature. 2014;510:417-21. doi:10.1038/nature13421.

17. Hsiao A, Ahmed AMS, Subramanian S, Griffin NW, Drewry LL, Petri WA, et al. Members of the human gut microbiota involved in recovery from Vibrio cholerae infection. Nature. 2014;515:423-6. doi:10.1038/nature13738.

18. Zackular JP, Baxter NT, Chen GY, Schloss PD. Manipulation of the gut microbiota reveals role in colon tumorigenesis. mSphere. 2015;1:e00001-15. doi:10.1128/msphere.00001-15.

19. Morgun A, Dzutsev A, Dong X, Greer RL, Sexton DJ, Ravel J, et al. Uncovering effects of antibiotics on the host and microbiota using transkingdom gene networks. Gut. 2015;64:1732-43. doi:10.1136/gutjnl-2014-308820.

20. Lichtman JS, Ferreyra JA, Ng KM, Smits SA, Sonnenburg JL, Elias JE. Host-microbiota interactions in the pathogenesis of antibiotic-associated diseases. Cell Rep. 2016;14:1049-61. doi:10.1016/j.celrep.2016.01.009.

21. Theriot CM, Koenigsknecht MJ, Carlson Jr PE, Hatton GE, Nelson AM, Li B, et al. Antibiotic-induced shifts in the mouse gut microbiome and metabolome increase susceptibility to Clostridium difficile infection. Nat Commun. 2014:5:3114. doi:10.1038/ncomms4114.

22. Gibson MK, Crofts TS, Dantas G. Antibiotics and the developing infant gut microbiota and resistome. Curr Opin Microbiol. 2015;27:51-6. doi:10.1016/j. mib.2015.07.007.

23. Hollister EB, Riehle K, Luna RA, Weidler EM, Rubio-Gonzales M, Mistretta TA, et al. Structure and function of the healthy pre-adolescent pediatric gut microbiome. Microbiome. 2015;3:36. doi:10.1186/s40168-015-0101-x.

24. Lim ES, Zhou Y, Zhao G, Bauer IK, Droit L, Ndao IM, et al. Early life dynamics of the human gut virome and bacterial microbiome in infants. Nat Med. 2015;21:1228-34. doi:10.1038/nm.3950

25. Parfrey LW, Walters WA, Knight R. Microbial eukaryotes in the human microbiome: ecology, evolution, and future directions. Front Microbiol. 2011;2:153. doi:10.3389/fmicb.2011.00153.

26. Aagaard K, Ma J, Antony KM, Ganu R, Petrosino J, Versalovic J. The placenta harbors a unique microbiome. Sci Transl Med. 2014;6:237ra65. doi:10.1126/ scitranslmed.3008599.

27. Mshvildadze M, Neu J, Shuster J, Theriaque D, Li N, Mai V. Intestinal microbial ecology in premature infants assessed with non-culture-based techniques. J Pediatr. 2010;156:20-5. doi:10.1016/j.jpeds.2009.06.063.

28. DiGiulio DB, Romero R, Amogan HP, Kusanovic JP, Bik EM, Gotsch F, et al. Microbial prevalence, diversity and abundance in amniotic fluid during preterm labor: a molecular and culture-based investigation. PLoS One. 2008;3:e3056. doi:10.1371/journal.pone.0003056.
29. Jimenez E, Fernandez L, Marin ML, Martin R, Odriozola JM, Nueno-Palop C et al. Isolation of commensal bacteria from umbilical cord blood of healthy neonates born by cesarean section. Curr Microbiol. 2005;51:270-4. doi:10.1007/s00284-005-0020-3.

30. Martinez de Tejada B. Antibiotic use and misuse during pregnancy and delivery: benefits and risks. Int J Environ Res Public Health. 2014;11:7993-8009. doi:10.3390/ijerph110807993.

31. Nahum GG, Uhl K, Kennedy DL. Antibiotic use in pregnancy and lactation: what is and is not known about teratogenic and toxic risks. Obstet Gynecol. 2006;107:1120-38. doi:10.1097/01.AOG.0000216197.26783.b5.

32. Dominguez-Bello MG, Costello EK, Contreras M, Magris M, Hidalgo G, Fierer $\mathrm{N}$, et al. Delivery mode shapes the acquisition and structure of the initial microbiota across multiple body habitats in newborns. Proc Natl Acad Sci U S A. 2010;107:11971-5. doi:10.1073/pnas.1002601107.

33. Makino H, Kushiro A, Ishikawa E, Kubota H, Gawad A, Sakai T, et al. Mother-to-infant transmission of intestinal bifidobacterial strains has an impact on the early development of vaginally delivered infant's microbiota. PLoS One. 2013;8:e78331. doi:10.1371/journal.pone.0078331.

34. Centers for Disease Control and Prevention (CDC). Community-associated methicillin-resistant Staphylococcus aureus infection among healthy newborns-Chicago and Los Angeles County, 2004. MMWR Morb Mortal Wkly Rep. 2006;55:329-32.

35. Roduit C, Scholtens S, de Jongste JC, Wijga AH, Gerritsen J, Postma DS, et al. Asthma at 8 years of age in children born by caesarean section. Thorax. 2009;64:107-13. doi:10.1136/thx.2008.100875.

36. Bonifacio E, Warncke K, Winkler C, Wallner M, Ziegler AG. Cesarean section and interferon-induced helicase gene polymorphisms combine to increase childhood type 1 diabetes risk. Diabetes. 2011;60:3300-6. doi:10.2337/db11-0729.

37. Rautava S, Luoto R, Salminen S, Isolauri E. Microbial contact during pregnancy, intestinal colonization and human disease. Nat Rev Gastroenterol Hepatol. 2012;9:565-76. doi:10.1038/nrgastro.2012.144.

38. La Rosa PS, Warner BB, Zhou Y, Weinstock GM, Sodergren E, Hall-Moore CM, et al. Patterned progression of bacterial populations in the premature infant gut. Proc Natl Acad Sci U S A. 2014;111:12522-7. doi:10.1073/pnas. 1409497111.

39. Verani JR, Schrag SJ. Group B streptococcal disease in infants: progress in prevention and continued challenges. Clin Perinatol. 2010;37:375-92. doi:10.1016/j.clp.2010.02.002.

40. Kuppala VS, Meinzen-Derr J, Morrow AL, Schibler KR. Prolonged initial empirical antibiotic treatment is associated with adverse outcomes in premature infants. J Pediatr. 2011;159:720-5. doi:10.1016/j.jpeds.2011.05.033.

41. Tanaka S, Kobayashi T, Songjinda P, Tateyama A, Tsubouchi M, Kiyohara C, et al. Influence of antibiotic exposure in the early postnatal period on the development of intestinal microbiota. FEMS Immunol Med Microbiol. 2009;56:80-7. doi:10.1111/j.1574-695X.2009.00553.x.

42. Greenwood C, Morrow AL, Lagomarcino AJ, Altaye M, Taft DH, Yu Z, et al. Early empiric antibiotic use in preterm infants is associated with lower bacterial diversity and higher relative abundance of Enterobacter. J Pediatr. 2014;165:23-9. doi:10.1016/j.jpeds.2014.01.010.

43. Moore AM, Ahmadi S, Patel S, Gibson MK, Wang B, Ndao Ml, et al. Gut resistome development in healthy twin pairs in the first year of life. Microbiome. 2015:3:27. doi:10.1186/s40168-015-0090-9.

44. Martin R, Heilig HG, Zoetendal EG, Jimenez E, Fernandez L, Smidt H, et al. Cultivation-independent assessment of the bacterial diversity of breast milk among healthy women. Res Microbiol. 2007;158:31-7. doi:10.1016/j.resmic. 2006.11.004.

45. Turnbaugh PJ, Ley RE, Mahowald MA, Magrini V, Mardis ER, Gordon J. An obesity-associated gut microbiome with increased capacity for energy harvest. Nature. 2006:444:1027-131. doi:10.1038/nature05414.

46. Sekirov I, Tam NM, Jogova M, Robertson ML, Li Y, Lupp C, et al. Antibioticinduced perturbations of the intestinal microbiota alter host susceptibility to enteric infection. Infect Immun. 2008;76:4726-36. doi:10.1128/iai.00319-08.

47. Azad MB, Bridgman SL, Becker AB, Kozyrskyj AL. Infant antibiotic exposure and the development of childhood overweight and central adiposity. Int J Obes (Lond). 2014;38:1290-8. doi:10.1038/ijo.2014.119.

48. Gordon Jl, Dewey KG, Mills DA, Medzhitov RM. The human gut microbiota and undernutrition. Sci Transl Med. 2012:4:137ps12. doi:10.1126/ scitranslmed.3004347.

49. Chang CY, Trehan I, Wang RJ, Thakwalakwa C, Maleta K, Deitchler M, et al. Children successfully treated for moderate acute malnutrition remain at risk 
for malnutrition and death in the subsequent year after recovery. J Nutr. 2013;143:215-20. doi:10.3945/jn.112.168047.

50. Trehan I, Goldbach HS, LaGrone LN, Meuli GJ, Wang RJ, Maleta KM, et al. Antibiotics as part of the management of severe acute malnutrition. N Engl J Med. 2013;368:425-35. doi:10.1056/NEJMoa1202851.

51. World Health Organization, World Food Programme, United Nations System Standing Committee on Nutrition, The United Nations Children's Fund. Community-based management of severe acute malnutrition. 2007. http://www.who.int/nutrition/topics/Statement_community_based_man_ sev_acute_mal_eng.pdf. Accessed 29 Mar 2016.

52. Allen HK, Stanton TB. Altered egos: antibiotic effects on food animal microbiomes. Annu Rev Microbiol. 2014;68:297-315. doi:10.1146/annurevmicro-091213-113052.

53. Cho I, Yamanishi S, Cox L, Methe BA, Zavadil J, Li K, et al. Antibiotics in early life alter the murine colonic microbiome and adiposity. Nature. 2012;488: 621-6. doi:10.1038/nature11400.

54. Gough EK, Moodie EE, Prendergast AJ, Johnson SM, Humphrey JH, Stoltzfus $\mathrm{RJ}$, et al. The impact of antibiotics on growth in children in low and middle income countries: systematic review and meta-analysis of randomised controlled trials. BMJ. 2014;348:g2267. doi:10.1136/bmj.g2267.

55. Centers for Disease Control and Prevention. Adult obesity facts. 2015. http://www.cdc.gov/obesity/data/adult.html. Accessed 29 Mar 2016.

56. Centers for Disease Control and Prevention. Childhood obesity facts. 2015. http://www.cdc.gov/obesity/data/childhood.html. Accessed 29 Mar 2016.

57. Jumpertz R, Le DS, Turnbaugh PJ, Trinidad C, Bogardus C, Gordon Jl, et al, Energy-balance studies reveal associations between gut microbes, caloric load, and nutrient absorption in humans. Am J Clin Nutr. 2011;94:58-65. doi:10.3945/ajcn.110.010132.

58. Turnbaugh PJ, Hamady M, Yatsunenko T, Cantarel BL, Duncan A, Ley RE, et al. A core gut microbiome in obese and lean twins. Nature. 2009;457:480-4. doi:10.1038/nature07540.

59. Cox LM, Blaser MJ. Antibiotics in early life and obesity. Nat Rev Endocrinol. 2015;11:182-90. doi:10.1038/nrendo.2014.210.

60. Mikkelsen KH, Knop FK, Frost M, Hallas J, Pottegard A. Use of antibiotics and risk of type 2 diabetes: a population-based case-control study. J Clin Endocrinol Metab. 2015;100:3633-40. doi:10.1210/jc.2015-2696.

61. Boursi B, Mamtani R, Haynes K, Yang YX. The effect of past antibiotic exposure on diabetes risk. Eur J Endocrinol. 2015:172:639-48. doi:10.1530/eje-14-1163.

62. Human Microbiome Project Consortium. Structure, function and diversity of the healthy human microbiome. Nature. 2012;486:207-14. doi:10.1038/ nature11234.

63. Raymond F, Ouameur AA, Deraspe M, lqbal N, Gingras H, Dridi B, et al. The initial state of the human gut microbiome determines its reshaping by antibiotics. ISME J. 2016;10:607-20. doi:10.1038/ismej.2015.148.

64. Clemente JC, Pehrsson EC, Blaser MJ, Sandhu K, Gao Z, Wang B, et al. The microbiome of uncontacted Amerindians. Sci Adv. 2015;1. doi:10.1126/ sciadv. 1500183.

65. Wakamoto Y, Dhar N, Chait R, Schneider K, Signorino-Gelo F, Leibler S, et al. Dynamic persistence of antibiotic-stressed mycobacteria. Science. 2013:339:91-5. doi:10.1126/science.1229858.

66. Yurtsev EA, Chao HX, Datta MS, Artemova T, Gore J. Bacterial cheating drives the population dynamics of cooperative antibiotic resistance plasmids. Mol Syst Biol. 2013;9:683. doi:10.1038/msb.2013.39.

67. De La Cochetiere MF, Durand T, Lepage P, Bourreille A, Galmiche JP, Dore J. Resilience of the dominant human fecal microbiota upon short-course antibiotic challenge. J Clin Microbiol. 2005;43:5588-92. doi:10.1128/jcm.43. 11.5588-5592.2005

68. Dethlefsen L, Huse S, Sogin ML, Relman DA. The pervasive effects of an antibiotic on the human gut microbiota, as revealed by deep $16 \mathrm{~S}$ rRNA sequencing. PLoS Biol. 2008;6:e280. doi:10.1371/journal.pbio.0060280.

69. Dethlefsen L, Relman DA. Incomplete recovery and individualized responses of the human distal gut microbiota to repeated antibiotic perturbation. Proc Natl Acad Sci U S A. 2011;108 Suppl 1:4554-61. doi:10.1073/pnas. 1000087107.

70. Jakobsson HE, Jernberg C, Andersson AF, Sjolund-Karlsson M, Jansson JK, Engstrand L. Short-term antibiotic treatment has differing long-term impacts on the human throat and gut microbiome. PLoS One. 2010;5:e9836. doi:10.1371/journal.pone.0009836.

71. Zaura E, Brandt BW, Teixeira de Mattos MJ, Buiis MJ, Caspers MP, Rashid MU, et al. Same exposure but two radically different responses to antibiotics: resilience of the salivary microbiome versus long-term microbial shifts in feces. mBio. 2015;6:e01693-15. doi:10.1128/mBio.01693-15.

72. Maurice CF, Haiser HJ, Turnbaugh PJ. Xenobiotics shape the physiology and gene expression of the active human gut microbiome. Cell. 2013;152:39-50 doi:10.1016/j.cell.2012.10.052.

73. Murray BE, Rensimer ER, DuPont HL. Emergence of high-level trimethoprim resistance in fecal Escherichia coli during oral administration of trimethoprim or trimethoprim-sulfamethoxazole. N Engl J Med. 1982;306:130-5. doi:10.1056/ nejm198201213060302.

74. Jernberg C, Lofmark S, Edlund C, Jansson JK. Long-term ecological impacts of antibiotic administration on the human intestinal microbiota. ISME J. 2007;1:56-66. doi:10.1038/ismej.2007.3.

75. Penders J, Stobberingh EE, Savelkoul PH, Wolffs PF. The human microbiome as a reservoir of antimicrobial resistance. Front Microbiol. 2013;4:87. doi:10.3389/fmicb.2013.00087.

76. Marild K, Ye W, Lebwohl B, Green PH, Blaser MJ, Card T, et al. Antibiotic exposure and the development of coeliac disease: a nationwide case-control study. BMC Gastroenterol. 2013;13:109. doi:10.1186/1471-230x-13-109.

77. Chang JY, Antonopoulos DA, Kalra A, Tonelli A, Khalife WT, Schmidt TM, et al. Decreased diversity of the fecal microbiome in recurrent Clostridium difficile-associated diarrhea. J Infect Dis. 2008;197:435-8. doi:10.1086/525047.

78. Buffie CG, Jarchum I, Equinda M, Lipuma L, Gobourne A, Viale A, et al. Profound alterations of intestinal microbiota following a single dose of clindamycin results in sustained susceptibility to Clostridium difficileinduced colitis. Infect Immun. 2012;80:62-73. doi:10.1128/iai.05496-11.

79. Centers for Disease Control and Prevention. Antibiotic resistance threats in the united states, 2013. 2013. http://www.cdc.gov/drugresistance/threatreport-2013. Accessed 29 Mar 2016.

80. Higa JT, Kelly CP. New drugs and strategies for management of Clostridium difficile colitis. J Intensive Care Med. 2014;29:190-9.

81. Bassis $C M$, Theriot $C M$, Young VB. Alteration of the murine gastrointestinal microbiota by tigecycline leads to increased susceptibility to Clostridium difficile infection. Antimicrob Agents Chemother. 2014;58:2767-74. doi:10.1128/aac.02262-13.

82. Ng KM, Ferreyra JA, Higginbottom SK, Lynch JB, Kashyap PC, Gopinath S, et al. Microbiota-liberated host sugars facilitate post-antibiotic expansion of enteric pathogens. Nature. 2013;502:96-9. doi:10.1038/nature12503.

83. Ferreyra JA, Wu KJ, Hryckowian AJ, Bouley DM, Weimer BC, Sonnenburg JL. Gut microbiota-produced succinate promotes $C$. difficile infection after antibiotic treatment or motility disturbance. Cell Host Microbe. 2014;16:770-7. doi:10.1016/j.chom.2014.11.003.

84. Jump RL, Polinkovsky A, Hurless K, Sitzlar B, Eckart K, Tomas M, et al. Metabolomics analysis identifies intestinal microbiota-derived biomarkers of colonization resistance in clindamycin-treated mice. PLoS One. 2014;9: e101267. doi:10.1371/journal.pone.0101267.

85. Zhao Y, Wu J, Li JV, Zhou NY, Tang H, Wang Y. Gut microbiota composition modifies fecal metabolic profiles in mice. J Proteome Res. 2013;12:2987-99. doi:10.1021/pr400263n.

86. Yap IK, Li JV, Saric J, Martin FP, Davies H, Wang Y, et al. Metabonomic and microbiological analysis of the dynamic effect of vancomycin-induced gut microbiota modification in the mouse. J Proteome Res. 2008;7:3718-28. doi:10.1021/pr700864x.

87. Romick-Rosendale LE, Goodpaster AM, Hanwright PJ, Patel NB, Wheeler ET, Chona DL, et al. NMR-based metabonomics analysis of mouse urine and fecal extracts following oral treatment with the broad-spectrum antibiotic enrofloxacin (Baytril). Magn Reson Chem. 2009;47 Suppl 1:S36-46. doi:10.1002/mrc.2511.

88. Antunes LC, Han J, Ferreira RB, Lolic P, Borchers CH, Finlay BB. Effect of antibiotic treatment on the intestinal metabolome. Antimicrob Agents Chemother. 2011;55:1494-503. doi:10.1128/aac.01664-10.

89. Zheng X, Xie G, Zhao A, Zhao L, Yao C, Chiu NH, et al. The footprints of gut microbial-mammalian co-metabolism. J Proteome Res. 2011;10:5512-22. doi:10.1021/pr2007945.

90. Buffie CG, Bucci V, Stein RR, McKenney PT, Ling L, Gobourne A, et al. Precision microbiome reconstitution restores bile acid mediated resistance to Clostridium difficile. Nature. 2015;517:205-8. doi:10.1038/ nature13828.

91. Knoop KA, McDonald KG, Kulkarni DH, Newberry RD. Antibiotics promote inflammation through the translocation of native commensal colonic bacteria. Gut. 2015. doi:10.1136/gutjnl-2014-309059. 
92. Bakken JS, Borody T, Brandt LJ, Brill JV, Demarco DC, Franzos MA, et al. Treating Clostridium difficile infection with fecal microbiota transplantation. Clin Gastroenterol Hepatol. 2011;9:1044-9. doi:10.1016/j.cgh.2011.08.014.

93. Alekshun MN, Levy SB. Targeting virulence to prevent infection: to kill or not to kill? Drug Discov Today Ther Strateg. 2004;1:483-9. doi:10.1016/j. ddstr.2004.10.006

94. Cegelski L, Marshall GR, Eldridge GR, Hultgren SJ. The biology and future prospects of antivirulence therapies. Nat Rev Microbiol. 2008;6:17-27. doi:10.1038/nrmicro1818.

95. Rasko DA, Sperandio V. Anti-virulence strategies to combat bacteriamediated disease. Nat Rev Drug Discov. 2010;9:117-28. doi:10.1038/nrd3013.

96. Zambelloni R, Marquez R, Roe AJ. Development of antivirulence compounds: a biochemical review. Chem Biol Drug Des. 2015;85:43-55. doi:10.1111/cbdd.12430.

97. Miller MB, Bassler BL. Quorum sensing in bacteria. Annu Rev Microbiol. 2001;55:165-99. doi:10.1146/annurev.micro.55.1.165.

98. Suga $\mathrm{H}$, Smith KM. Molecular mechanisms of bacterial quorum sensing as a new drug target. Curr Opin Chem Biol. 2003;7:586-91.

99. Dong $Y H$, Wang LH, Xu JL, Zhang HB, Zhang XF, Zhang LH. Quenching quorum-sensing-dependent bacterial infection by an $\mathrm{N}$-acyl homoserine lactonase. Nature. 2001:411:813-7. doi:10.1038/35081101.

100. Rasmussen TB, Manefield M, Andersen JB, Eberl L, Anthoni U, Christophersen C, et al. How Delisea pulchra furanones affect quorum sensing and swarming motility in Serratia liquefaciens MG1. Microbiology. 2000;146:3237-44. doi:10.1099/00221287-146-12-3237.

101. Manefield M, Rasmussen TB, Henzter M, Andersen JB, Steinberg P, Kjelleberg $S$, et al. Halogenated furanones inhibit quorum sensing through accelerated LuxR turnover. Microbiology. 2002;148:1119-27. doi:10.1099/00221287-148-4-1119.

102. Hentzer M, Riedel K, Rasmussen TB, Heydorn A, Andersen JB, Parsek MR, et al. Inhibition of quorum sensing in Pseudomonas aeruginosa biofilm bacteria by a halogenated furanone compound. Microbiology. 2002;148:87-102. doi:10.1099/00221287-148-1-87.

103. Smith M, Moon H, Chowrira G, Kunst L. Heterologous expression of a fatty acid hydroxylase gene in developing seeds of Arabidopsis thaliana. Planta. 2003:217:507-16. doi:10.1007/s00425-003-1015-6.

104. Smith KM, Bu Y, Suga H. Induction and inhibition of Pseudomonas aeruginosa quorum sensing by synthetic autoinducer analogs. Chem Biol. 2003;10:81-9.

105. Starkey M, Lepine F, Maura D, Bandyopadhaya A, Lesic B, He J, et al. Identification of anti-virulence compounds that disrupt quorum-sensing regulated acute and persistent pathogenicity. PLoS Pathog. 2014;10:e1004321. doi:10.1371/journal.ppat.1004321.

106. Maeda T, Garcia-Contreras R, Pu M, Sheng L, Garcia LR, Tomas M, et al. Quorum quenching quandary: resistance to antivirulence compounds. ISME J. 2012;6:493-501. doi:10.1038/ismej.2011.122.

107. Garcia-Contreras R, Martinez-Vazquez M, Velazquez Guadarrama N, Villegas Paneda AG, Hashimoto T, Maeda T, et al. Resistance to the quorum-quenching compounds brominated furanone C-30 and 5-fluorouracil in Pseudomonas aeruginosa clinical isolates. Pathog Dis. 2013;68:8-11. doi:10.1111/2049-632x.12039.

108. Allen RC, Popat R, Diggle SP, Brown SP. Targeting virulence: can we make evolution-proof drugs? Nat Rev Microbiol. 2014;12:300-8. doi:10.1038/ nrmicro3232.

109. Bender KO, Garland M, Ferreyra JA, Hryckowian AJ, Child MA, Puri AW, et al. A small-molecule antivirulence agent for treating Clostridium difficile infection. Sci Transl Med. 2015;7:306ra148. doi:10.1126/scitransImed.aac9103.

110. Shoop WL, Xiong Y, Wiltsie J, Woods A, Guo J, Pivnichny JV, et al. Anthrax lethal factor inhibition. Proc Natl Acad Sci U S A. 2005;102:7958-63. doi:10. 1073/pnas.0502159102

111. Karginov VA, Nestorovich EM, Moayeri M, Leppla SH, Bezrukov SM. Blocking anthrax lethal toxin at the protective antigen channel by using structureinspired drug design. Proc Natl Acad Sci U S A. 2005;102:15075-80. doi:10.1073/pnas.0507488102.

112. Armstrong GD, Rowe PC, Goodyer P, Orrbine E, Klassen TP, Wells G, et al. A phase I study of chemically synthesized verotoxin (Shiga-like toxin) Pk-trisaccharide receptors attached to chromosorb for preventing hemolytic-uremic syndrome. J Infect Dis. 1995;171:1042-5.

113. Report of The Lancet Special Commission on the relative strengths of diphtheria antitoxic serums. Lancet. 1896;148:182-95. doi:10.1016/S01406736(01)72399-9
114. Lopez EL, Contrini MM, Glatstein E, Gonzalez Ayala S, Santoro R, Allende D, et al. Safety and pharmacokinetics of urtoxazumab, a humanized monoclonal antibody, against Shiga-like toxin 2 in healthy adults and in pediatric patients infected with Shiga-like toxin-producing Escherichia coli. Antimicrob Agents Chemother. 2010;54:239-43. doi:10.1128/aac.00343-09.

115. Yamagami S, Motoki M, Kimura T, Izumi H, Takeda T, Katsuura Y, et al. Efficacy of postinfection treatment with anti-Shiga toxin (Stx) 2 humanized monoclonal antibody TMA-15 in mice lethally challenged with Stx-producing Escherichia coli. J Infect Dis. 2001;184:738-42. doi:10.1086/323082

116. Chen Z, Moayeri M, Zhou YH, Leppla S, Emerson S, Sebrell A, et al. Efficient neutralization of anthrax toxin by chimpanzee monoclonal antibodies against protective antigen. J Infect Dis. 2006;193:625-33. doi:10.1086/ 500148

117. Hung DT, Shakhnovich EA, Pierson E, Mekalanos JJ. Small-molecule inhibitor of Vibrio cholerae virulence and intestinal colonization. Science. 2005:310:670-4. doi:10.1126/science.1116739.

118. Shakhnovich EA, Hung DT, Pierson E, Lee K, Mekalanos JJ. Virstatin inhibits dimerization of the transcriptional activator ToxT. Proc Natl Acad Sci U S A. 2007;104:2372-7. doi:10.1073/pnas.0611643104.

119. Felise HB, Nguyen HV, Pfuetzner RA, Barry KC, Jackson SR, Blanc MP, et al. An inhibitor of gram-negative bacterial virulence protein secretion. Cell Host Microbe. 2008;4:325-36. doi:10.1016/j.chom.2008.08.001.

120. Wang D, Zetterstrom CE, Gabrielsen M, Beckham KS, Tree JJ, Macdonald SE, et al. Identification of bacterial target proteins for the salicylidene acylhydrazide class of virulence-blocking compounds. J Biol Chem. 2011;286:29922-31. doi:10.1074/jbc.M111.233858.

121. Kline T, Felise HB, Barry KC, Jackson SR, Nguyen HV, Miller SI. Substituted 2-imino-5-arylidenethiazolidin-4-one inhibitors of bacterial type III secretion. J Med Chem. 2008:51:7065-74. doi:10.1021/jm8004515.

122. Veenendaal AK, Sundin C, Blocker AJ. Small-molecule type III secretion system inhibitors block assembly of the Shigella type III secreton. J Bacteriol. 2009;191:563-70. doi:10.1128/jb.01004-08.

123. Muschiol S, Bailey L, Gylfe A, Sundin C, Hultenby K, Bergstrom S, et al. A small-molecule inhibitor of type III secretion inhibits different stages of the infectious cycle of Chlamydia trachomatis. Proc Natl Acad Sci U S A 2006;103:14566-71. doi:10.1073/pnas.0606412103.

124. Bailey L, Gylfe A, Sundin C, Muschiol S, Elofsson M, Nordstrom P, et al. Small molecule inhibitors of type III secretion in Yersinia block the Chlamydia pneumoniae infection cycle. FEBS Lett. 2007;581:587-95. doi:10.1016/j. febslet.2007.01.013.

125. Kauppi AM, Nordfelth $\mathrm{R}$, Uvell H, Wolf-Watz H, Elofsson M. Targeting bacterial virulence: inhibitors of type III secretion in Yersinia. Chem Biol. 2003;10:241-9.

126. Smith MA, Coincon M, Paschos A, Jolicoeur B, Lavallee P, Sygusch J, et al. Identification of the binding site of Brucella VirB8 interaction inhibitors. Chem Biol. 2012;19:1041-8. doi:10.1016/j.chembiol.2012.07.007.

127. Greene SE, Pinkner JS, Chorell E, Dodson KW, Shaffer CL, Conover MS, et al. Pilicide ec240 disrupts virulence circuits in uropathogenic Escherichia coli. mBio. 2014;5:e02038. doi:10.1128/mBio.02038-14.

128. Pinkner JS, Remaut $\mathrm{H}$, Buelens $\mathrm{F}$, Miller $\mathrm{E}$, Aberg $\mathrm{V}$, Pemberton $\mathrm{N}$, et al. Rationally designed small compounds inhibit pilus biogenesis in uropathogenic bacteria. Proc Natl Acad Sci U S A. 2006;103:17897-902. doi:10.1073/pnas.0606795103

129. Berg V, Sellstedt M, Hedenstrom M, Pinkner JS, Hultaren SJ, Almqvist F. Design, synthesis and evaluation of peptidomimetics based on substituted bicyclic 2-pyridones-targeting virulence of uropathogenic E. coli. Bioorg Med Chem. 2006;14:7563-81. doi:10.1016/j.bmc.2006.07.017.

130. Svensson A, Larsson A, Emtenas H, Hedenstrom M, Fex T, Hultgren SJ, et al. Design and evaluation of pilicides: potential novel antibacterial agents directed against uropathogenic Escherichia coli. Chembiochem. 2001;2:915-8

131. Liu Cl, Liu GY, Song Y, Yin F, Hensler ME, Jeng WY, et al. A cholesterol biosynthesis inhibitor blocks Staphylococcus aureus virulence. Science. 2008;319:1391-4. doi:10.1126/science.1153018.

132. de la Fuente-Núñez C, Reffuveille F, Haney EF, Straus SK, Hancock REW. Broad-spectrum anti-biofilm peptide that targets a cellular stress response. PLoS Pathog. 2014;10:e1004152. doi:10.1371/journal.ppat.1004152.

133. Ross-Gillespie A, Weigert M, Brown SP, Kummerli R. Gallium-mediated siderophore quenching as an evolutionarily robust antibacterial treatment Evol Med Public Health. 2014;2014:18-29. doi:10.1093/emph/eou003. 
134. Hill C, Guarner F, Reid G, Gibson GR, Merenstein DJ, Pot B, et al. Expert consensus document. The International Scientific Association for Probiotic and Prebiotics consensus statement on the scope and appropriate use of the term probiotic. Nat Rev Gastroenterol Hepatol. 2014;11:506-14. doi:10.1038/nrgastro.2014.66.

135. McFarland LV. Use of probiotics to correct dysbiosis of normal microbiota following disease or disruptive events: a systematic review. BMJ Open. 2014;4, e005047. doi:10.1136/bmjopen-2014-005047.

136. Johnston BC, Ma SS, Goldenberg JZ, Thorlund K, Vandvik PO, Loeb M, et al. Probiotics for the prevention of Clostridium difficile-associated diarrhea: a systematic review and meta-analysis. Ann Intern Med. 2012;157:878-88. doi:10.7326/0003-4819-157-12-201212180-00563.

137. Johnston BC, Goldenberg JZ, Vandvik PO, Sun X, Guyatt GH. Probiotics for the prevention of pediatric antibiotic-associated diarrhea. Cochrane Database Syst Rev. 2011;CD004827. doi:10.1002/14651858.CD004827.pub3

138. Videlock EJ, Cremonini F. Meta-analysis: probiotics in antibiotic-associated diarrhoea. Alimentary Pharmacol Therapeut. 2012;35:1355-69. doi:10.1111/j. 1365-2036.2012.05104.x.

139. Hempel S, Newberry SJ, Maher AR, Wang Z, Miles JN, Shanman R, et al. Probiotics for the prevention and treatment of antibiotic-associated diarrhea: a systematic review and meta-analysis. JAMA. 2012;307:1959-69. doi:10.1001/jama.2012.3507.

140. Allen SJ, Martinez EG, Gregorio GV, Dans LF. Probiotics for treating acute infectious diarrhoea. Cochrane Database Syst Rev. 2010;CD003048. doi:10.1002/14651858.CD003048.pub3.

141. Lievin-Le Moal V, Servin AL. Anti-infective activities of lactobacillus strains in the human intestinal microbiota: from probiotics to gastrointestinal anti-infectious biotherapeutic agents. Clin Microbiol Rev. 2014;27:167-99. doi:10.1128/cmr.00080-13.

142. Corr SC, Li Y, Riedel CU, O'Toole PW, Hill C, Gahan CG. Bacteriocin production as a mechanism for the antiinfective activity of Lactobacillus salivarius UCC118. Proc Natl Acad Sci U S A. 2007;104:7617-21. doi:10.1073/pnas.0700440104.

143. Cimperman L, Bayless G, Best K, Diligente A, Mordarski B, Oster M, et al. A randomized, double-blind, placebo-controlled pilot study of Lactobacillus reuteri ATCC 55730 for the prevention of antibiotic-associated diarrhea in hospitalized adults. J Clin Gastroenterol. 2011;45:785-9. doi:10.1097/MCG. Ob013e3182166a42.

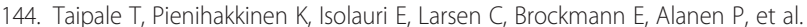
Bifidobacterium animalis subsp. lactis BB-12 in reducing the risk of infections in infancy. Br J Nutr. 2011;105:409-16. doi:10.1017/ s0007114510003685.

145. Schultz M. Clinical use of E. coli Nissle 1917 in inflammatory bowel disease. Inflamm Bowel Dis. 2008;14:1012-8. doi:10.1002/ibd.20377.

146. Tannock GW, Tiong IS, Priest P, Munro K, Taylor C, Richardson A, et al. Testing probiotic strain Escherichia coli Nissle 1917 (Mutaflor) for its ability to reduce carriage of multidrug-resistant $\mathrm{E}$. coli by elderly residents in long-term care facilities. J Med Microbiol. 2011;60:366-70. doi:10.1099/jmm. 0.025874-0.

147. Geldart K, Borrero J, Kaznessis YN. Chloride-inducible expression vector for delivery of antimicrobial peptides targeting antibiotic-resistant Enterococcus faecium. Appl Environ Microbiol. 2015;81:3889-97. doi:10.1128/aem.00227-15.

148. Pereira VB, Saraiva TD, Souza BM, Zurita-Turk M, Azevedo MS, De Castro CP, et al. Development of a new DNA vaccine based on mycobacterial ESAT-6 antigen delivered by recombinant invasive Lactococcus lactis FnBPA+. Appl Microbiol Biotechnol. 2015;99:1817-26. doi:10.1007/s00253-014-6285-3.

149. Gupta S, Bram EE, Weiss R. Genetically programmable pathogen sense and destroy. ACS Syn Bio. 2013;2:715-23. doi:10.1021/sb4000417.

150. Hwang IY, Tan MH, Koh E, Ho CL, Poh CL, Chang MW. Reprogramming microbes to be pathogen-seeking killers. ACS Synth Biol. 2014;3:228-37. doi:10.1021/sb400077j.

151. Yaung SJ, Deng L, Li N, Braff JL, Church GM, Bry L, et al. Improving microbial fitness in the mammalian gut by in vivo temporal functional metagenomics. Mol Syst Biol. 2015;11:788. doi:10.15252/msb.20145866

152. Stripling J, Kumar R, Baddley JW, Nellore A, Dixon P, Howard D, et al. Loss of vancomycin-resistant Enterococcus fecal dominance in an organ transplant patient with Clostridium difficile colitis after fecal microbiota transplant. Open Forum Infect Dis. 2015;2:ofv078. doi:10.1093/ofid/ofv078.

153. Cammarota G, Masucci L, laniro G, Bibbo S, Dinoi G, Costamagna G, et al. Randomised clinical trial: faecal microbiota transplantation by colonoscopy vs. vancomycin for the treatment of recurrent Clostridium difficile infection. Aliment Pharmacol Ther. 2015;41:835-43. doi:10.1111/apt.13144.
154. Wyatt JP. Oxford handbook of emergency medicine. Oxford: Oxford University Press; 2006

155. Sulakvelidze A, Alavidze Z, Morris JG. Bacteriophage therapy. Antimicrob Agents Chemother. 2001:45:649-59. doi:10.1128/aac.45.3.649-659.2001.

156. Khalifa L, Brosh Y, Gelman D, Coppenhagen-Glazer S, Beyth S, Poradosu-Cohen R, et al. Targeting Enterococcus faecalis biofilms with phage therapy. Appl Environ Microbiol. 2015;81:2696-705. doi:10.1128/aem.00096-15.

157. Kong M, Ryu S. Bacteriophage PBC1 and its endolysin as an antimicrobial agent against Bacillus cereus. Appl Environ Microbiol. 2015;81:2274-83. doi:10.1128/aem.03485-14.

158. Olszak T, Zarnowiec P, Kaca W, Danis-Wlodarczyk K, Augustyniak D, Drevinek $P$, et al. In vitro and in vivo antibacterial activity of environmental bacteriophages against Pseudomonas aeruginosa strains from cystic fibrosis patients. Appl Microbiol Biotechnol. 2015;99:6021-33. doi:10.1007/s00253015-6492-6.

159. Smith HW, Huggins MB, Shaw KM. The control of experimental Escherichia coli diarrhoea in calves by means of bacteriophages. J Gen Microbiol. 1987;133:1111-26. doi:10.1099/00221287-133-5-1111.

160. Filippov AA, Sergueev KV, He Y, Huang XZ, Gnade BT, Mueller AJ, et al. Bacteriophage-resistant mutants in Yersinia pestis: identification of phage receptors and attenuation for mice. PLoS One. 2011;6:e25486. doi:10.1371/journal.pone.0025486.

161. Citorik RJ, Mimee M, Lu TK. Bacteriophage-based synthetic biology for the study of infectious diseases. Curr Opin Microbiol. 2014;19:59-69. doi:10.1016/j.mib.2014.05.022.

162. Lu TK, Collins JJ. Dispersing biofilms with engineered enzymatic bacteriophage Proc Natl Acad Sci U S A. 2007;104:11197-202. doi:10.1073/pnas.0704624104.

163. Pei R, Lamas-Samanamud GR. Inhibition of biofilm formation by $T 7$ bacteriophages producing quorum-quenching enzymes. Appl Environ Microbiol. 2014:80:5340-8. doi:10.1128/aem.01434-14.

164. Bikard D, Euler CW, Jiang W, Nussenzweig PM, Goldberg GW, Duportet X, et al. Exploiting CRISPR-Cas nucleases to produce sequence-specific antimicrobials. Nat Biotechnol. 2014;32:1146-50. doi:10.1038/nbt.3043.

165. Citorik RJ, Mimee M, Lu TK. Sequence-specific antimicrobials using efficiently delivered RNA-guided nucleases. Nat Biotechnol. 2014;32:1141-5. doi:10.1038/nbt.3011.

166. Yosef I, Manor M, Kiro R, Qimron U. Temperate and lytic bacteriophages programmed to sensitize and kill antibiotic-resistant bacteria. Proc Natl Acad Sci U S A. 2015;112:7267-72. doi:10.1073/pnas.1500107112.

167. Gipponi M, Sciutto C, Accornero L, Bonassi S, Raso C, Vignolo C, et al. Assessing modifications of the intestinal bacterial flora in patients on long-term oral treatment with bacampicillin or amoxicillin: a random study. Chemioterapia. 1985:4:214-7.

168. Hernandez E, Bargiela R, Diez MS, Friedrichs A, Perez-Cobas AE, Gosalbes MJ, et al. Functional consequences of microbial shifts in the human gastrointestinal tract linked to antibiotic treatment and obesity. Gut Microbes. 2013:4:306-15. doi:10.4161/gmic.25321.

169. Sunakawa K, Akita H, Iwata S, Sato Y. The influence of cefotaxime on intestinal flora and bleeding diathesis in infants and neonates, compared with other beta-lactams. J Antimicrob Chemother. 1984;14 Suppl B:317-24.

170. Lambert-Zechovsky N, Bingen E, Aujard Y, Mathieu H. Impact of cefotaxime on the fecal flora in children. Infection. 1985;13 Suppl 1:S140-4.

171. Brismar B, Edlund C, Malmborg AS, Nord CE. Ciprofloxacin concentrations and impact of the colon microflora in patients undergoing colorectal surgery. Antimicrob Agents Chemother. 1990;34:481-3.

172. Kager L, Liljeqvist L, Malmborg AS, Nord CE. Effect of clindamycin prophylaxis on the colonic microflora in patients undergoing colorectal surgery. Antimicrob Agents Chemother. 1981;20:736-40.

173. Brismar B, Edlund C, Nord CE. Comparative effects of clarithromycin and erythromycin on the normal intestinal microflora. Scand J Infect Dis. 1991;23:635-42.

174. Bergan T, Nord CE, Thorsteinsson SB. Effect of meropenem on the intestinal microflora. Eur J Clin Microbiol Infect Dis. 1991;10:524-7.

175. Nord CE, Bergan T, Thorsteinsson SB. Impact of ticarcillin/clavulanate on the intestinal microflora. J Antimicrob Chemother. 1989;24 Suppl B:221-6.

176. Nord CE, Sillerström E, Wahlund E. Effect of tigecycline on normal oropharyngeal and intestinal microflora. Antimicrob Agents Chemother. 2006:50:3375-80, doi:10.1128/aac.00373-06.

177. Vrieze A, Out C, Fuentes S, Jonker L, Reuling I, Kootte RS, et al. Impact of oral vancomycin on gut microbiota, bile acid metabolism, and insulin sensitivity. J Hepatol. 2014;60:824-31. doi:10.1016/j.jhep.2013.11.034. 
178. Prudhomme M, Attaiech L, Sanchez G, Martin B, Claverys JP. Antibiotic stress induces genetic transformability in the human pathogen Streptococcus pneumoniae. Science. 2006;313:89-92. doi:10.1126/science.1127912.

179. Shevchuk YM, Pharm D, Conly JM. Antibiotic-associated hypoprothrombinemia. Infect Dis Newsl. 1992;11:43-6. doi:10.1016/0278-2316(92)90002-U.

180. Perez-Cobas AE, Gosalbes MJ, Friedrichs A, Knecht H, Artacho A, Eismann K, et al. Gut microbiota disturbance during antibiotic therapy: a multi-omic approach. Gut. 2013;62:1591-601. doi:10.1136/gutjnl-2012-303184.

Submit your next manuscript to BioMed Central and we will help you at every step:

- We accept pre-submission inquiries

- Our selector tool helps you to find the most relevant journal

- We provide round the clock customer support

- Convenient online submission

- Thorough peer review

- Inclusion in PubMed and all major indexing services

- Maximum visibility for your research

Submit your manuscript at www.biomedcentral.com/submit 